\title{
20. Modelling in-house radon potential using Tellus data and geology to supplement in- house radon measurements
}

\author{
Don Appleton $^{\mathrm{I}}$ and James Hodgson ${ }^{2}$
}

How to cite this chapter: Appleton, J.D. and Hodgson, J.A., 2016 Modelling inhouse radon potential using Tellus data and geology to supplement in-house radon measurements' in M.E. Young

(ed.), Unearthed: impacts of the Tellus surveys of the north of Ireland. Dublin. Royal Irish

Academy.

DOI:10.3318/

978-1-908996-88-6.ch20
It is well known that naturally occurring radon gas rising from the ground and accumulating in dwellings and workplaces is a cause of lung cancer, particularly among smokers. In the UK and Ireland, campaigns to measure and suppress radon in buildings have been proceeding for several years. This chapter considers how additional data from geological mapping and data from the Tellus surveys can improve our estimation of in-house radon potential. In the Republic of Ireland radon potential mapping has hitherto been based solely on indoor radon measurements, while in Northern Ireland indoor radon readings are supplemented with geological data. New radon modelling with Tellus airborne gamma-ray spectrometry and soil geochemistry, in combination with geological data and indoor radon measurements, has in some settings produced maps with more detailed spatial resolution. The process has identified some differences between the Tellus modelled maps and the current indoor radon maps. These should be validated with additional radon measurements, especially where the Tellus maps indicate higher radon potential and where in-house radon measurements are sparse. The Tellus-based radon maps should be used as an aid in future in-house radon measurement campaigns.

\section{INTRODUCTION}

\section{Radon in the environment}

Radon is produced by the radioactive decay of radium $\left({ }^{226} \mathrm{Ra}\right)$, which in turn is derived from the radioactive decay of the uranium isotope ${ }^{238} \mathrm{U}$. Uranium is found in small quantities in all soils and rocks, although the amount varies from place to place. The rate of release of radon from rocks and soils is largely controlled by their uranium and radium concentrations, grain size and the types of minerals in which the uranium occurs (Appleton, 2013).

${ }^{\mathrm{I}}$ British Geological Survey, Keyworth.

${ }^{2}$ Geological Survey of Ireland, Dublin. 
Radon can accumulate in buildings, where it provides about $50-55 \%$ of the total radiation dose to the average person in the UK and Ireland (Watson et al., 2005; O'Connor et al., 2014). The most important factors controlling the migration and accumulation of radon in buildings include:

- characteristics of the bedrock and soils that affect fluid transport, including porosity and permeability;

- the construction of the building, its use and ventilation;

- environmental factors such as temperature (increased heating in buildings during the colder months causes a chimney effect which draws soil gases including radon into the property), and wind speed and direction, which can increase the chimney effect.

Radon concentrations in outdoor air in the UK and Ireland are generally low, on average 4 to $6 \mathrm{~Bq} \mathrm{~m}^{-3}$, while the population-weighted average in indoor air in Northern Ireland dwellings is $19 \mathrm{~Bq} \mathrm{~m}^{-3}$ (Green et al., 2009). The average indoor radon concentration in Ireland is $89 \mathrm{~Bq} \mathrm{~m}^{-3}$ (Fennell et al., 2002). An extreme concentration of $49,000 \mathrm{~Bq}$ $\mathrm{m}^{-3}$ was measured at a dwelling in County Kerry.

\section{Managing health risks}

Radon decays to form radioactive particles that can enter the body by inhalation. Inhalation of these short-lived decay products of radon has been linked to an increase in the risk of developing lung cancer. Breathing radon indoors is the second largest cause of lung cancer deaths after smoking. An estimated 1100 lung cancer deaths per year in the UK were caused by radon, representing $3.3 \%$ of total lung cancer deaths (HPA, 2009). Some of the highest indoor radon concentrations found anywhere in Europe have been found in homes and workplaces in Ireland, where it is estimated that radon is linked to 150-200 cancer deaths annually (RPII and HSE, 2010). Most radon-related deaths are caused by a combination of radon and smoking.

An Action Level (AL) for radon in homes of $200 \mathrm{~Bq} \mathrm{~m}^{-3}$ has been established in the UK. The same concentration is called the Reference Level (RL) in Ireland. Parts of the UK with $1 \%$ probability or more of homes being at or above $200 \mathrm{~Bq} \mathrm{~m}^{-3}$ are designated as radon Affected Areas.

Radon potential (RP) maps are produced in Northern Ireland (Daraktchieva et al., 2015) and Ireland (Fennell et al., 2002) that indicate the probability that new or existing houses will exceed the AL or RL of $200 \mathrm{~Bq} \mathrm{~m}^{-3}$. The maps are used (a) to assess whether preventative (protective) measures need to be installed in new dwellings and other buildings (BRE, 2001; DEHLG, 2008); (b) for cost-effective targeting of radon monitoring in existing dwellings and workplaces in order to identify buildings that need to have radon remediation measures installed; and (c) to provide a radon risk assessment for homebuyers and sellers. An RP map can indicate the relative radon risk for a building in a particular 
locality, but it cannot predict the radon risk for an individual building. This can only be established by having the building tested, but RP maps are an important tool for prioritising or identifying areas in which buildings should be tested.

RP maps are based on measurements in homes, but they can be used to predict the likely extent of the local radon hazard in all buildings. The information is therefore relevant to employers in assessing workplace risks. For workplaces the Action or Reference Level is $400 \mathrm{~Bq} \mathrm{~m}^{-3}$, which takes into account that most people spend much more time at home than at work. Employers' responsibilities are set out for Northern Ireland in the Health and Safety at Work Regulations (HSENI, 2000) and for Ireland in the Safety, Health and Welfare at Work Act 2005 (HSA, 2005). Guidance on how to apply the radon maps in assessing workplace radon is available from the Health and Safety Executive Northern Ireland (HSENI) website, www.hseni.gov.uk. Equivalent guidance in Ireland is given by the EPA (RPII, 2008).

\section{DATA AND METHODOLOGY}

In order to help prevent the public from having high exposures to radon, it is necessary to identify the areas most at risk. The potential for high indoor radon concentrations depends on multiple factors, including the amount of ${ }^{226} \mathrm{Ra}$ in the ground underneath buildings and the permeability of the ground. As a result, indoor radon tends to be correlated with local geology (Appleton and Miles, 2010). The probability of homes in Northern Ireland having radon concentrations above $200 \mathrm{~Bq} \mathrm{~m}^{-3}$ was until very recently estimated on the basis of the results of radon measurements in homes, grouped by $1 \mathrm{~km}$ squares where there are sufficient results in the square, or interpolated from the nearest measurements for squares where there are too few results (Green et al., 2009). In Ireland, measurement data are grouped by $10 \mathrm{~km}$ grid squares (Fennell et al., 2002). In the UK an integrated mapping method has been developed to use indoor radon results in conjunction with geological boundaries to map RP with greater accuracy and detail than is possible using the 1 $\mathrm{km}$ grid square RP map based solely on indoor radon measurements (Miles and Appleton, 2005; Appleton et al., 2015; Daraktchieva et al., 2015).

Uranium concentrations in surface rocks and soils, estimated by airborne surveys of gamma rays from ${ }^{214} \mathrm{Bi}$, and referred to as $\mathrm{eU}$ (equivalent uranium), have been used to inform RP mapping in many countries. The geochemical and airborne radiometric results of the Tellus and Tellus Border Projects allow existing RP maps to be refined in Northern Ireland, the Border Region and the Tralee-Castleisland area (County Kerry). Modelling $\mathrm{RP}$ using the Tellus data in combination with indoor radon measurements is described below. Data collection and survey procedures are described in earlier chapters of this volume. 


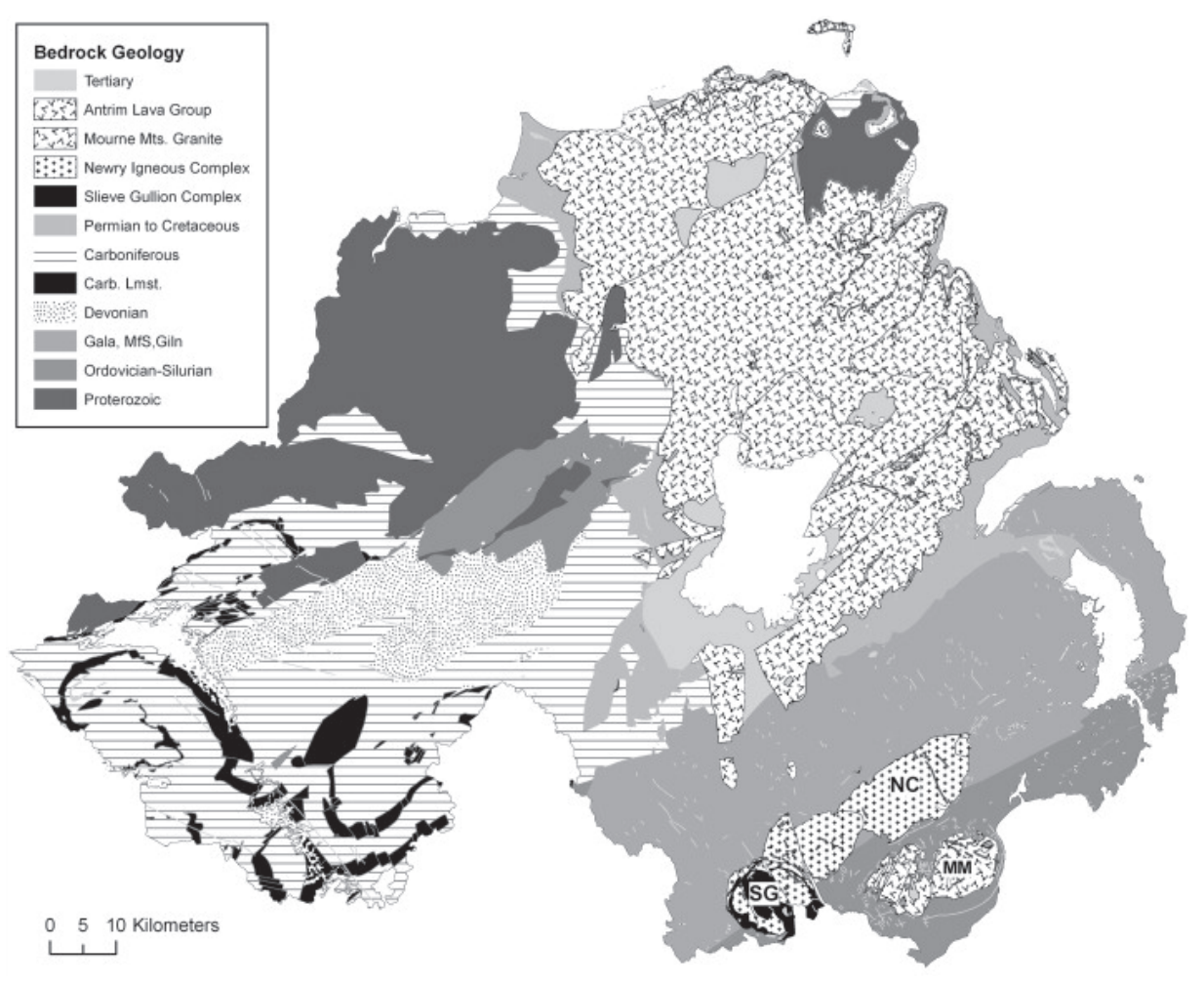

\section{NORTHERN IRELAND}

Predictive modelling of relevant Tellus airborne and soil geochemical parameters (Appleton et al., 2011a) was used in an attempt to refine the radon map based solely on indoor radon data and 1:250,000 scale geology (Figs 20.1 and 20.2) . National and terrain-specific linear regression models were statistically validated against the radon map based on indoor radon and geology in order to assess whether RP maps derived by predictive modelling of ground permeability, airborne gamma-ray spectrometry and soil geochemical data could usefully inform future indoor radon measurement programmes. Indoor radon measurements were available for approximately 23,000 dwellings, with accurate $( \pm 10 \mathrm{~m})$ locations available for $90 \%$ of the dwellings. The average measurement density is 1.6 indoor radon measurements per $\mathrm{km}^{2}$, although measurements are clustered both in urban areas and especially in known high-radon areas.

The RP map produced from Tellus data using separate linear regression models for different geological terrains provides the best visual and statistical agreement with the RP map based solely on indoor radon and geology (compare Figs 20.2 and 20.3). However, RP maps produced using the Tellus data appear to underestimate RP, especially where the highest RP is indicated on the indoor radon/geology RP map. For example, there are several areas underlain by Argyll Group metasediments, Gala Group greywackes, Hawick Group greywackes (e.g. Lecale peninsula), the Newry Granodiorite and Carboniferous

Figure 20.1. Simplified bedrock geology of Northern Ireland. MM, Mourne Mountains Granite; SG, Slieve Gullion Complex; NC, Newry Igneous Complex (BGS (C) NERC; Geological and topography data (C) Crown Copyright, 2011; Appleton et al. (2011a)). 


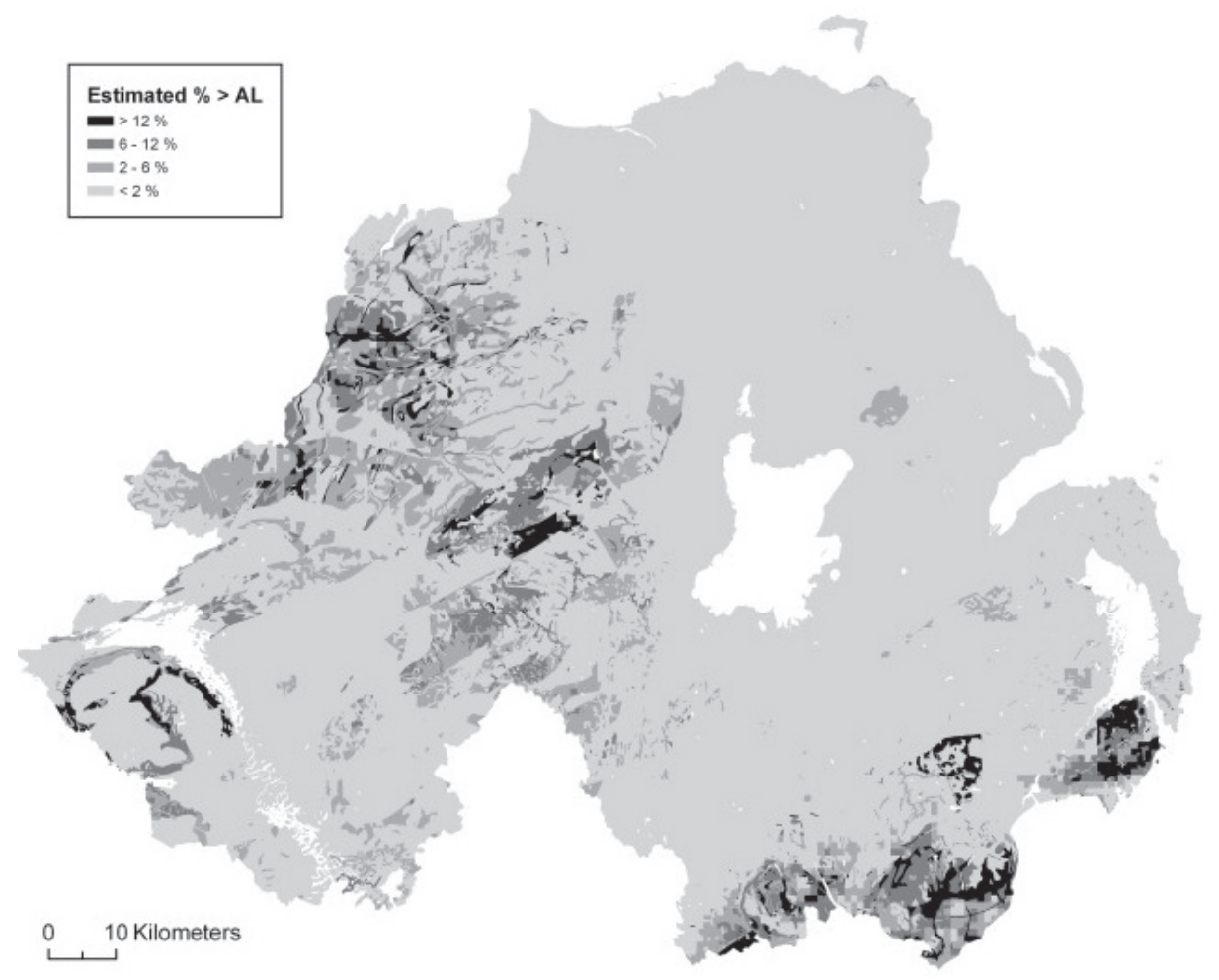

Figure 20.2. Radon potential (estimated $\%>\mathrm{AL}$ ) map based on 1:250,000 scale geology and indoor radon data (BGS (C) NERC; Geological and topography data (C) Crown Copyright, 2011; Appleton et al. (2011a)).

limestone where the RP estimated from the Tellus data is substantially less than that shown on the indoor radon/geology map (Figs 20.2 and 20.3). This underestimation may be because airborne $\mathrm{eU}$ values (calculated from ${ }^{214} \mathrm{Bi}$, a daughter product of radon, ${ }^{222} \mathrm{Rn}$ ) are in some cases reduced where the radon concentration is lower in the top $30 \mathrm{~cm}$ of the soil than at greater depth, as a result of the loss of radon from the surface rocks and soils to air. In Northern Ireland only $13 \%$ of the variation of indoor radon was explained by 1:250,000 scale geology, whereas geology explains $69 \%$ of the variation of airborne $\mathrm{eU}$ data and $83 \%$ of the variation of soil $U$ data. So it is not entirely surprising that the agreement between the indoor radon/geology RP and RP modelled from the Tellus data in Northern Ireland is less than perfect. Subsequent to this study based on indoor radon data and 1:250,000 scale geology (Appleton et al., 2011a), a new radon map has been published based on indoor radon data and more spatially accurate 1:10,000 scale digital geological data (Appleton et al., 2015; Daraktchieva et al., 2015).

\section{Tralee-Castleisland and Cavan areas, Republic of Ireland}

Tellus Airborne gamma-ray spectrometer data for the Tralee-Castleisland area of County Kerry and part of County Cavan were compared statistically with in-house radon measurements in conjunction with geological and ground permeability data to establish linear regression models and produce RP maps (Appleton et al., 2011b). 


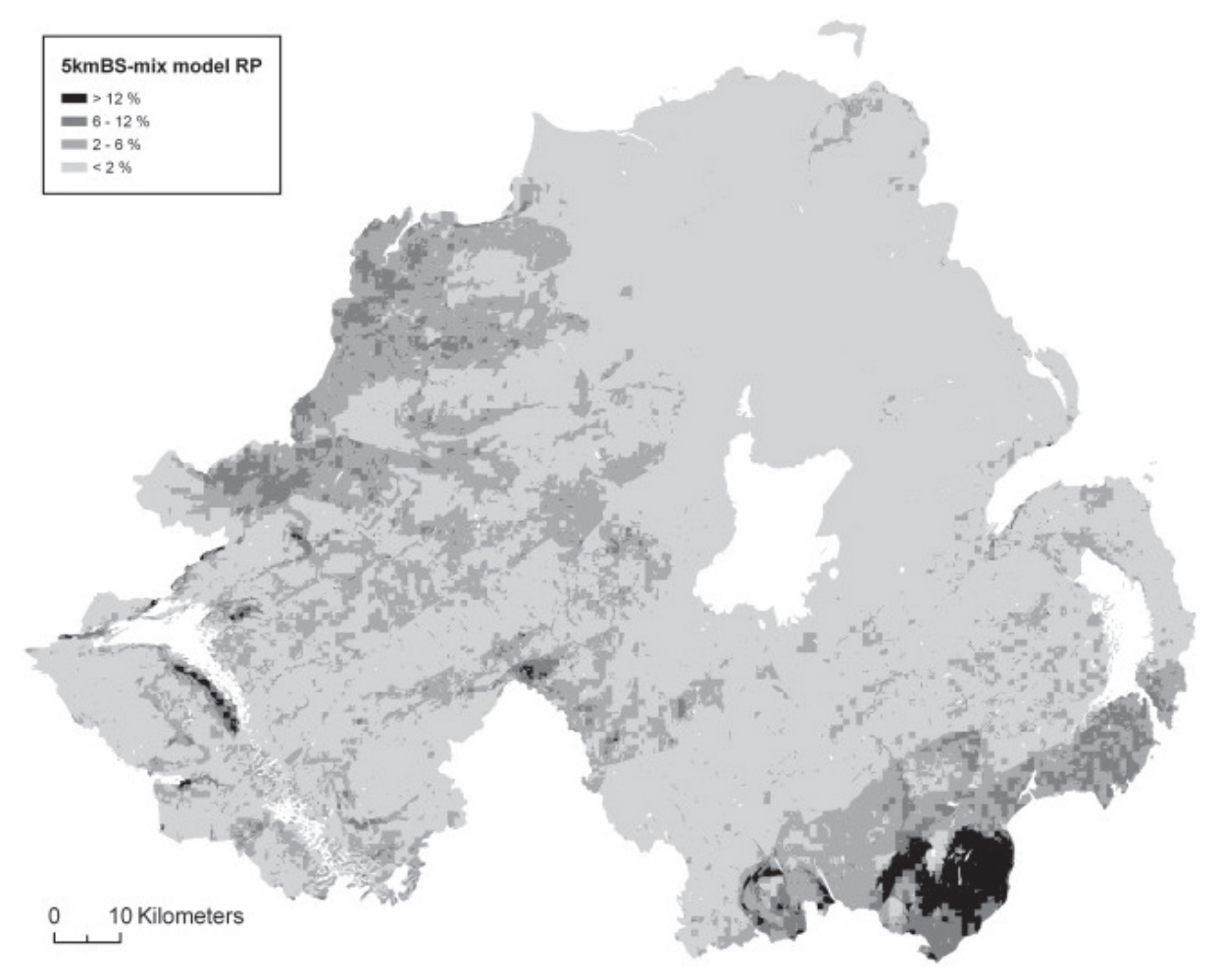

The best agreement between the percentage exceeding the RL (\%>RL), estimated from indoor radon data and modelled RP for six townlands in the Tralee-Castleisland area is produced by models based on the Tellus eU data and ground permeability.

Different regression models were required for the four geological terrains in the Cavan area (Appleton et al., 2011b). Reasonably close agreement was obtained between (a) the percentage of dwellings exceeding the RL, estimated from indoor radon data for seven townland areas and (b) modelled RP estimated from eU data using the terrain-specific models.

RP maps derived using the Tellus data show more spatial detail than the current RPII $10 \mathrm{~km}$ map in both Tralee-Castleisland (Figs 20.4a and 20.4b) and Cavan (see Figs 10 and 11 in Appleton et al., 2011b).

\section{The Border Region, Republic of Ireland}

Multivariate linear regression analysis was used to determine the relationship between indoor radon probability data, airborne gamma-ray spectrometry, soil chemistry and geological parameters (Hodgson and Carey, 2013). All data were averaged within individual $1 \mathrm{~km}$ grid squares and correlated with indoor radon probability values expressed as a percentage exceeding the Reference Level. A subset of indoor radon measurements, not used in the model development, was used to validate the model. Modelling uncertainties

Figure 20.3. Radon potential (estimated \% > AL) map modelled from eU and permeability using the $5 \mathrm{kmBS}$-mix linear regression model (BGS @ NERC; Geological and topography data (C) Crown Copyright, 2011; Appleton et al. (2011a)). 

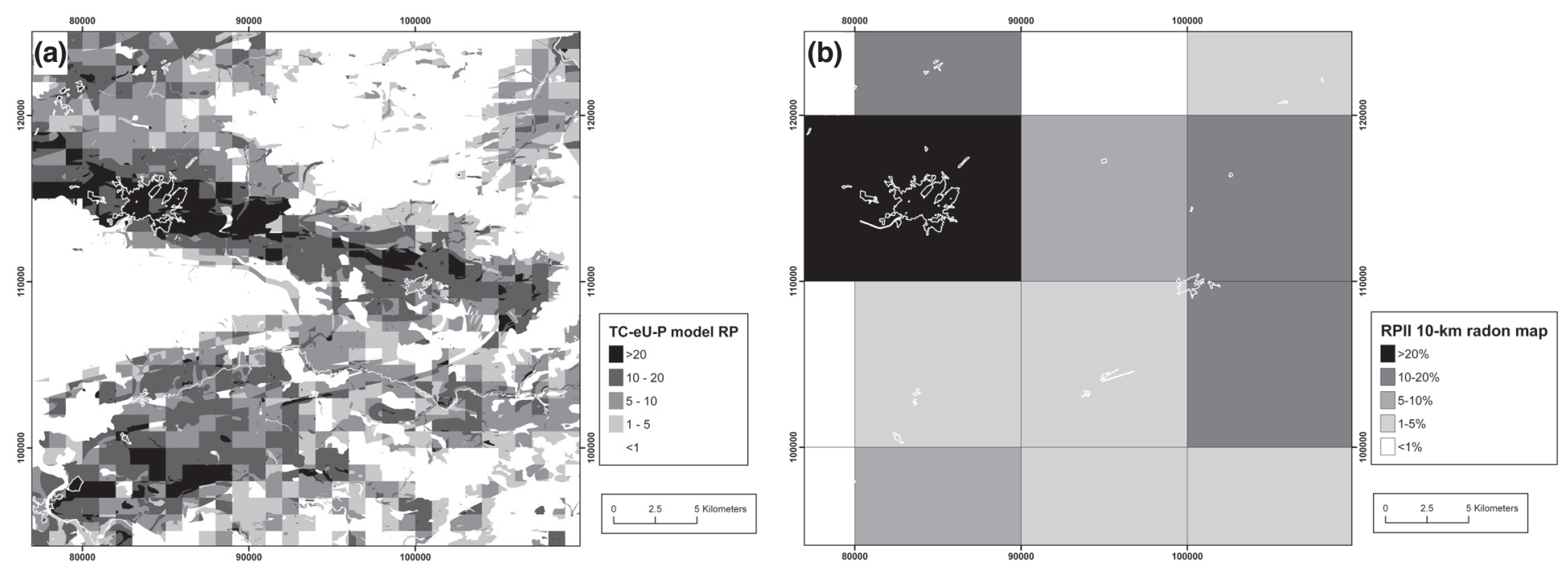

Figure 20.4 (a). Radon potential $(\%>\mathrm{RL})$ map of the Tralee-Castleisland area produced using the TC-eU-P linear regression model (urban areas outlined in white) (BGS

(C) NERC; derived from geological data (C) GSI, 2011

some boundaries derived from data prepared by Spatial Analysis Group, TEAGASC,

Kinsealy Research Centre,

funded by NDP; Appleton et al. (2011b)). (b). RPII

$10-\mathrm{km}$ grid radon map of the Tralee-Castleisland area (main urban areas outlined in white; map redrawn from the data in Fennell et al. (2002)) (BGS $\odot$ NERC; Appleton $e t$ al. (2011b)). include the influence on the indoor radon measurements of (a) house type, method of construction and ventilation; (b) house location uncertainty; and (c) the small number of radon measurements. Indoor radon measurements were available for only 5010 dwellings and exact $( \pm 10 \mathrm{~m})$ locations for only $10 \%$ of these.

Equivalent uranium, groundwater recharge coefficient and the degree of karstification of the mapped bedrock were identified as the only statistically significant independent variables for modelling RP using $1 \mathrm{~km}$ averaging. Groundwater recharge, calculated from soil thickness, permeability and the capacity of the underlying aquifer to accept recharge through fractures or porosity, was used as an indicator of total ground permeability (Hodgson and Carey, 2013). The linear regression model was applied to every grid square across the region to estimate RP $(\%>\mathrm{RL})$. Modelled $\%>\mathrm{RL}$ shows generally good agreement with the RPII $10 \mathrm{~km}$ grid National Radon Map, but with more detailed spatial resolution.

The modelled RP map predicts a number of zones with high $(>20) \%>$ RL. Many of these agree with the existing national radon map of Ireland (Fig. 20.5), in particular with granite in Donegal (A in Fig. 20.6); Carboniferous limestones and uraniferous shales in southern Donegal, Sligo, Leitrim (B, C, D) and north County Meath (G), and finally granite and Lower Palaeozoic greywackes in northern Louth and the Cooley peninsula (F). However, previously unknown radon highs that do not correlate with the national radon map are predicted by the modelled RP map within central Sligo and Leitrim, southern Donegal and a band running through northern Monaghan (E in Fig. 20.6). These may be due to (a) the different scales of the modelled RP and national radon maps, (b) real but previously unidentified radon highs or (c) artefacts caused by high eU, karst and/or groundwater recharge values. These areas identified using the Tellus data warrant further investigation to eliminate the risk of unidentified high-risk radon areas. 


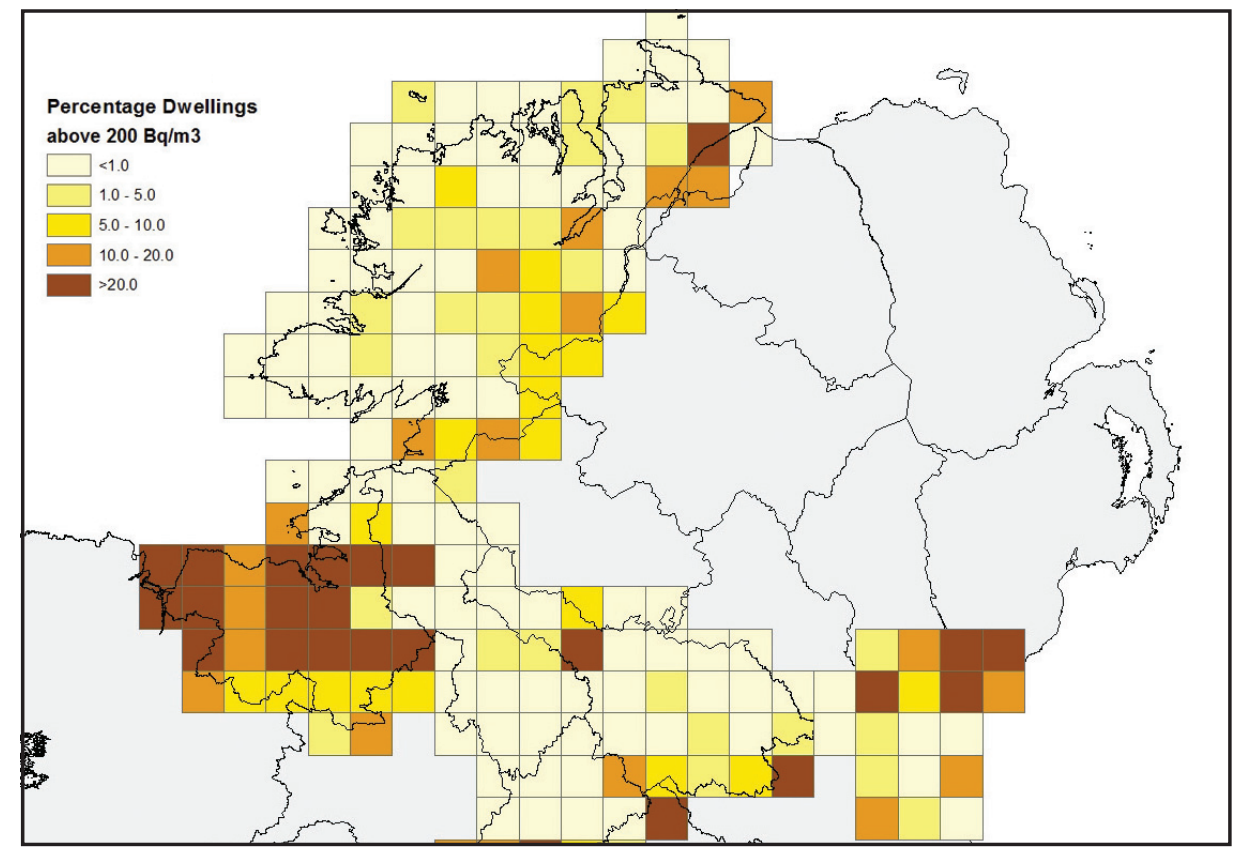

Figure 20.5. Extract for

Border Region from $10 \mathrm{~km}$ grid National Radon Map of Ireland (C GSI, 2015; map redrawn from the data in Fennell et al. (2002)).

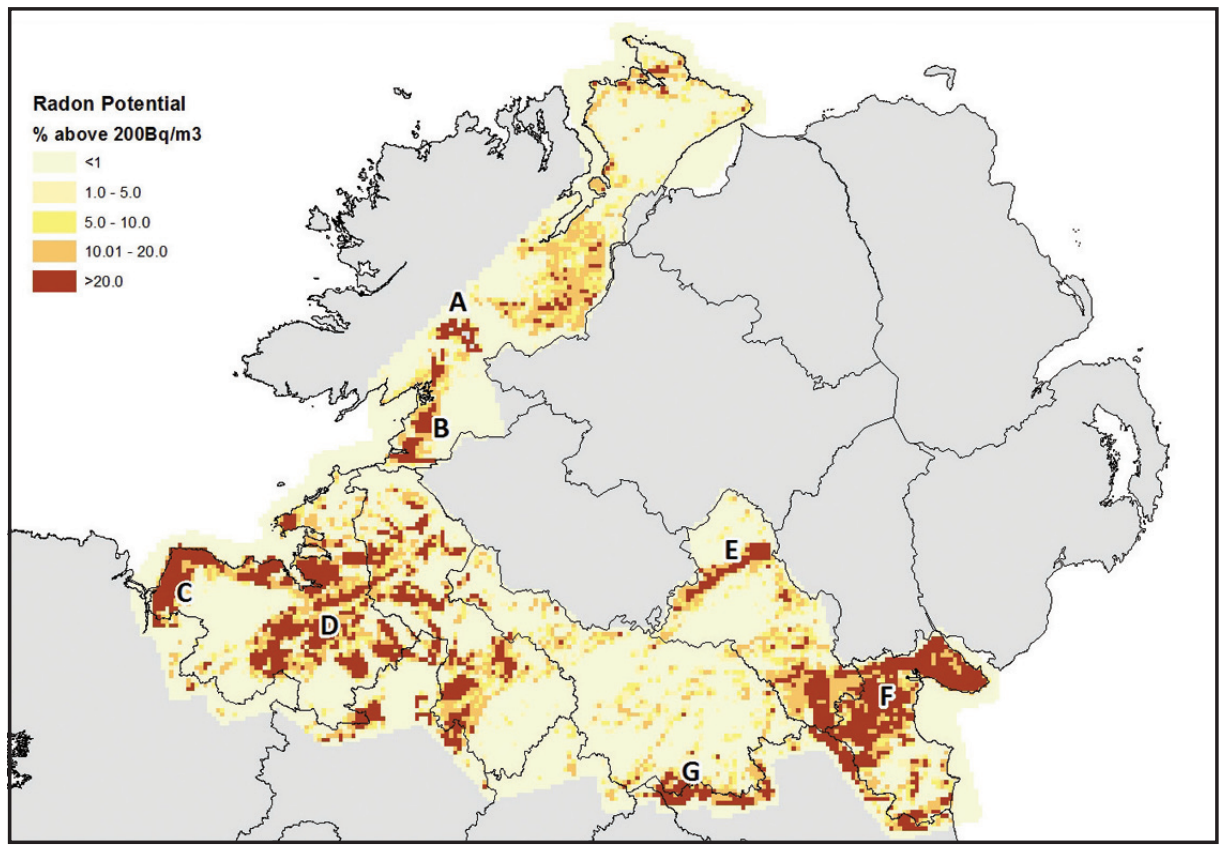

Figure 20.6 Output from model TB_RN_Mod10 for Border Region derived from $\mathrm{eU}$, groundwater recharge and karst values, with anomalous zones labelled A-G; details within text (C) GSI, 2015; adapted from Fig. 10, Hodgson and Carey, 2013)) 


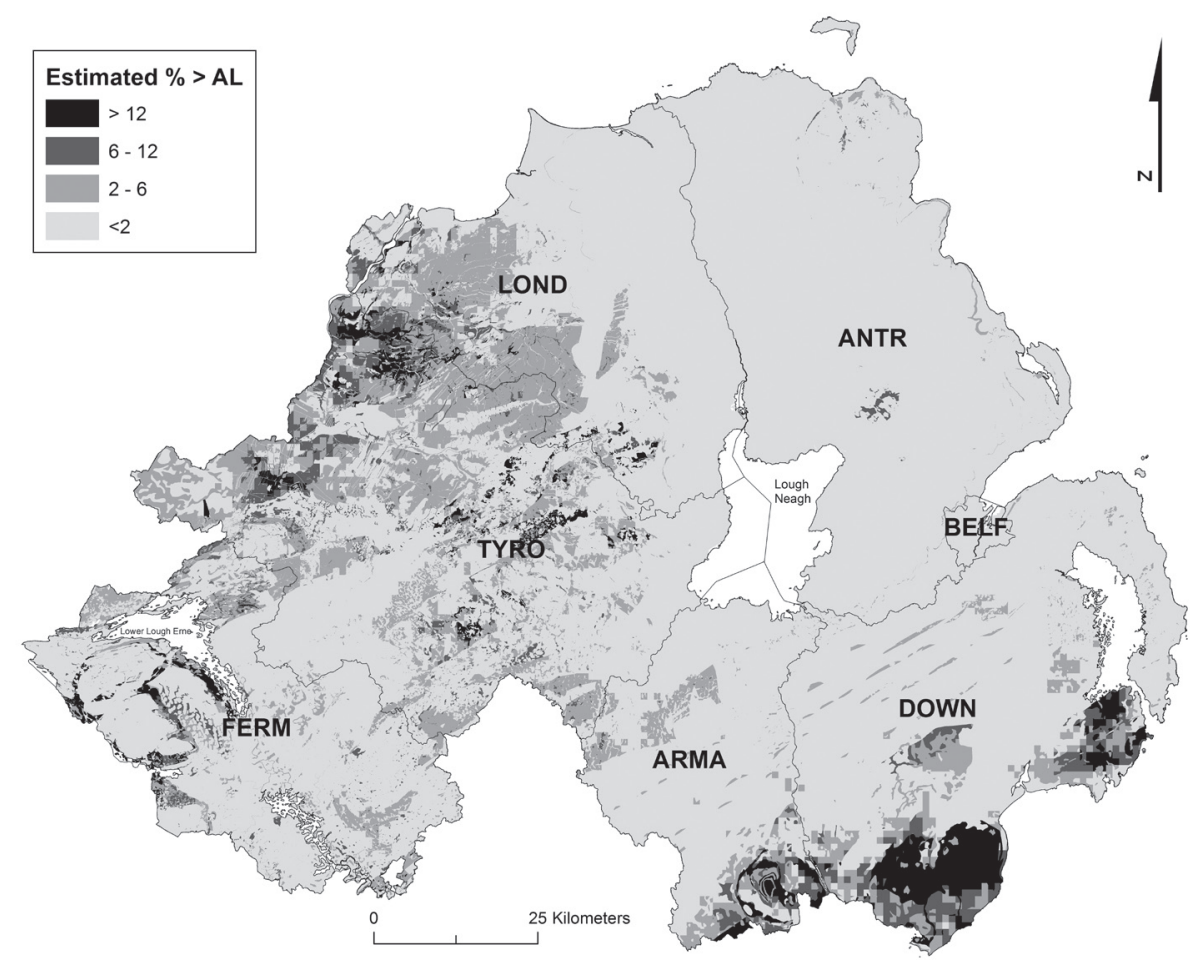

Figure 20.7. Joint HPE-BGS radon potential map of Northern Ireland showing the percentage of dwellings estimated to exceed the radon Action Level (ANTR

= Antrim; ARMA = Armagh; BELF $=$ Belfast ; DOWN =

Down; FERM = Fermanagh; LOND = Londonderry; TYRO $=$ Tyrone $)(B G S$ (C) NERC; Geological and topography data (C) Crown Copyright, 2011; Appleton et al. (2015)).

Disparities exist between the modelled RP (Fig. 20.6) and the new radon map for adjacent areas in Northern Ireland (Fig. 20.7). In most cases the modelled RP in Ireland is higher than the RP in Northern Ireland. This could be caused by the use of a regression model dominated by Carboniferous limestone data in the Border Region. This linear regression model may not be appropriate for other geological terrains, as previously demonstrated in Northern Ireland (Appleton et al., 2011a) and in the Cavan area (Appleton et al., 2011b).

\section{CONCLUSIONS AND RECOMMENDATIONS}

In Ireland, radon mapping is currently based solely on indoor radon measurements while in Northern Ireland indoor radon data are combined with geological data (Daraktchieva et al., 2015). However, differences have been identified between the official maps and radon potential (RP) modelled from eU, karst and ground water recharge in the Border Region, and from eU and ground permeability in Northern Ireland, Cavan and the Tralee-Castleisland areas.

It is recommended that additional indoor measurements should be made where the official and RP maps modelled from eU and geology/soil variables disagree, especially in areas where (a) the modelled RP is higher and (b) there are few indoor radon measurements. In the Border Region, it is recommended that subsoil information and the 
accurately geo-referenced indoor radon data should be used to improve the models. The need for terrain-specific models should also be investigated using the combined Northern Ireland and Border Region data.

Radon mapping based on targeted in-house measurements is more cost-effective than using an airborne survey carried out only for the purpose of producing RP maps, although in Ireland mapping can be slower due to limited uptake of in-house measurements by home owners. As a consequence, airborne gamma-ray spectrometry data should be used for radon mapping only if the data are collected as part of a multidisciplinary, multidetector survey such as the Tellus projects. Radon maps based on the data from such surveys are a valuable output that can be used to help target future in-house radon measurement campaigns designed to identify dwellings and other buildings with radon above the Action or Reference Level.

\section{ACKNOWLEDGEMENTS}

JDA publishes with the permission of the Executive Director of the British Geological Survey (NERC). JAH publishes with the permission of the Director of the Geological Survey of Ireland.

\section{REFERENCES}

Appleton, J.D., 2013 'Radon in air and water' in O. Selinus (ed.) Essentials of Medical Geology (revised edition), 239-78. Dordrecht. Springer. Available at http://nora.nerc.ac.uk/502215/. http://dx.doi.org/10.1007/978-94-007-4375-5_11.

Appleton J.D., Daraktchieva Z. and Young M.E., 2015 'Geological controls on radon potential in Northern Ireland', Proceedings of the Geologists' Association, 126, 3, 328-45. Available at http://nora.nerc.ac.uk/511253/. http://dx.doi.org/10.1016/j.pgeola.2014.07.001.

Appleton, J.D., Doyle, E., Fenton, D. and Organo, C., 2011b 'Radon potential mapping of the Tralee-Castleisland and Cavan areas (Ireland) based on airborne gamma-ray spectrometry and geology', Journal of Radiological Protection, 31, 211-35. Available at http://nora.nerc.ac.uk/14599/. http://iopscience.iop.org/0952-4746/31/2/002/.

Appleton, J.D. and Miles, J.C.H., 2010 'A statistical evaluation of the geogenic controls on indoor radon concentrations and radon risk', Journal of Environmental Radioactivity, 101, 10, 799-803. Available at http://nora.nerc.ac.uk/12853/. http://dx.doi.org/10.1016/j.jenvrad.2009.06.002.

Appleton, J.D., Miles, J.C.H. and Young, M.E., 2011a 'Comparison of Northern Ireland radon maps based on indoor radon measurements and geology with maps derived by predictive modelling of airborneradiometricand ground permeability data', Scienceof the TotalEnvironment, 409, 1572-83. Available at http://nora.nerc.ac.uk/14598/. http://dx.doi.org/10.1016/j.scitotenv.2011.01.023

Building Research Establishment (BRE), 2001 Radon: Guidance on Protective Measures for New Buildings in Northern Ireland. Watford, UK. Building Research Establishment report BR-413.

Daraktchieva, Z., Appleton J.D., Rees D.M., Adlam K.A.M., Myers A.H., Hodgson S., McColl N.P., Wasson G.R. and Peake L.J., 2015 Indicative Atlas of Radon in Northern Ireland. Chilton, UK. Public Health England report PHE-CRCE-017. Available at http://www.ukradon.org/resources/.

Department of the Environment, Heritage and Local Government (DEHLG), 2008 Technical Guidance Document C - Site Preparation and Resistance to Moisture. Dublin. Stationery Office. Available at http://www.environ.ie/en/TGD/. 
Fennell, S.G., Mackin, G.M., Madden, J.S., McGarry, A.T., Duffy, J.T., O’Colmain, M., Colgan, P.A. and Pollard D., 2002 Radon in Dwellings: The Irish National Radon Survey. Dublin. Radiological Protection Institute of Ireland.

Green, B.M.R., Larmour, R., Miles, J.C.H., Rees, D.M. and Ledgerwood, F.K., 2009 Radon in Dwellings in Northern Ireland. Chilton, UK. Health Protection Agency report HPA-RPD-061.

Health and Safety Authority (HSA), 2005 Safety, Health and Welfare Act 2005 (No. 10 of 2005). Dublin. Available at http://www.hsa.ie/eng/Legislation/Acts/Safety_Health_and_Welfare_at_Work/.

Health and Safety Executive of Northern Ireland (HSENI), 2000 Management of Health and Safety at Work Regulations (Northern Ireland). Belfast.

Health Protection Agency (HPA), 2009 Radon and Public Health. Report prepared by the Subgroup on Radon Epidemiology of the Independent Advisory Group on Ionising Radiation. Chilton, UK. Health Protection Agency Report HPA-RCE-11. Available at https://www.gov.uk/government/collections/radiation-hpa-rce-report-series.

Hodgson J. A. and Carey S., 2013 Radon Risk Predictive Modelling Using Airborne Geophysical Data in the Border Region of Ireland. Tellus Border Project Report TBGPH06, Geological Survey of Ireland and Geological Survey of Northern Ireland. Available at http://www.tellusborder.eu/Library.htm.

Miles, J.C.H. and Appleton, J.D., 2005 'Mapping variation in radon potential both between and within geological units', Journal of Radiological Protection, 25, 257-76. Available at http://nora.nerc.ac.uk/18361/. http://dx.doi.org/10.1088/0952-4746/25/3/003.

O'Connor, C., Currivan, L., Cunningham, N., Kelleher, K., Lewis, M., Long, S., McGinnity, P., Smith, V. and McMahon, C., 2014 Radiation doses received by the Irish population. Dublin. Radiological Protection Agency of Ireland, report RPII 14/02. Available at https://www.epa.ie/search/.

Radiological Protection Institute of Ireland (RPII), 2008 Guidance Notes on the Actions an Employer May Take if High Radon Concentrations are Found in a Work Place. Dublin. Radiological Protection Institute of Ireland. Available at https://www.epa.ie/search/.

Radiological Protection Institute of Ireland (RPII) \& Health Service Executive (HSE), 2010 Radon Gas in Ireland. Joint position statement. Dublin. Available at https://www.epa.ie/search/.

Watson, S.J., Jones, A.L., Oatway, W.B. and Hughes, J.S., 2005 Ionising Radiation Exposure of the UK Population: 2005 Review. Chilton, UK. Health Protection Agency report HPA-RPD-001. 
Unearthed: impacts of the Tellus surveys of the north of Ireland

First published in 2016 by the

Royal Irish Academy

19 Dawson Street

Dublin 2

www.ria.ie

Copyright (C) 2016 Royal Irish Academy

ISBN: 978-1-908996-88-6

The articles in this book are open access and distributed under the terms of the Creative Commons Attribution 4.0 licence, which permits unrestricted use, distribution and reproduction in any medium, provided the original authors and source are credited. To view a copy of this licence, visit https://creativecommons.org/licenses/by/4.0/

Except where noted:

Geological mapping for Northern Ireland / Tellus data are provided by the Geological Survey of Northern Ireland.

Geological mapping for Ireland / Tellus Border data are provided by the Geological Survey of Ireland.

Topographic mapping for Northern Ireland is derived from Land and Propery Services Open Data and contains public sector information licensed under the Open Government Licence v3.0. (http://www.nationalarchives.gov.uk/doc/open-governmentlicence/version/3/).

Topographic mapping for Ireland is derived from Ordnance Survey of Ireland Open Data (https://creativecommons.org/licenses/by/4.0/legalcode).

While every effort has been made to contact and obtain permission from holders of copyright, if any involuntary infringement of copyright has occurred, sincere apologies are offered, and the owner of such copyright is requested to contact the publisher.

British Library Cataloguing-in-Publication Data. A catalogue record is available from the British Library.

Design: Alex Donald, Geological Survey of Northern Ireland.

Index: Brendan O'Brien.

Printed in Poland by L\&C Printing Group. 


\section{Table of Contents:}

\section{Prelim}

DOI: https://doi.org/10.7486/DRI.b851k323d

\section{Chapter 1}

The Tellus geosciences surveys of the north of Ireland: context, delivery and impacts

DOI: https://doi.org/10.7486/DRI.st74s528d

\section{Chapter 2}

The Tellus airborne geophysical surveys and results DOI: https://doi.org/10.7486/DRI.t148tx96z

\section{Chapter 3}

The Tellus geochemical surveys, results and applications

DOI: https://doi.org/10.7486/DRI.t722wq645

\section{Chapter 4}

Stakeholder engagement for regional geoscientific surveying: the Tellus Border communications campaign

DOI: https://doi.org/10.7486/DRI.w089fr763

\section{Chapter 5}

Mineral resources and Tellus: the essential balance DOI: https://doi.org/10.7486/DRI.wd37kb12s

\section{Chapter 6}

Gold exploration in the north of Ireland: new targets from the Tellus Projects

DOI: https://doi.org/10.7486/DRI.wh24m696v

\section{Chapter 7}

Using soil geochemistry to investigate gold and base metal distribution and dispersal in the glaciated north of Ireland

DOI: https://doi.org/10.7486/DRI.wm11n3806

\section{Chapter 8}

Critical metals for hightechnology applications: mineral exploration potential in the north of Ireland DOI: https://doi.org/10.7486/DRI.wp98p0649

\section{Chapter 9}

A natural laboratory for critical metals investigations in the Mourne Mountains granites

DOI: https://doi.org/10.7486/DRI.cc08ww45f

\section{Chapter 10}

Geothermal potential of granitic rocks of the Mourne Mountains

DOI: https://doi.org/10.7486/DRI.ff36jm09f

\section{Chapter 11}

Shape and intrusion history of the Late Caledonian

Newry Igneous Complex, Northern Ireland

DOI: https://doi.org/10.7486/DRI.2v248822m

\section{Chapter 12}

Using Tellus data to enhance targeting of volcanogenic massive sulphide mineralisation in the Tyrone Igneous Complex

DOI: https://doi.org/10.7486/DRI.5x226w262

\section{Chapter 13}

The geological significance of electrical conductivity anomalies of the Ordovician- Silurian Moffat Shale Group, Northern Ireland

DOI: https://doi.org/10.7486/DRI.6m31f4149

\section{Chapter 14}

Faults, intrusions and flood basalts: the Cenozoic structure of the north of Ireland

DOI: https://doi.org/10.7486/DRI.90205h306

\section{Chapter 15}

Information for agriculture from regional geochemical surveys: the example of soil $\mathrm{pH}$ in the Tellus and Tellus Border data

DOI: https://doi.org/10.7486/DRI.dv14c8060

\section{Chapter 16}

An ecohydrological investigation of wetlands in the border counties of Ireland: a framework for a holistic understanding of wetland systems DOI: https://doi.org/10.7486/DRI.hd775d90j 
Chapter 17

Assessing nutrient enrichment risk to groundwaterdependent ecosystems in the border counties of Ireland DOI: https://doi.org/10.7486/DRI.k356pk18j

\section{Chapter 18}

Mapping the terrestrial gamma radiation dose

DOI: https://doi.org/10.7486/DRI.k930rb86z

\section{Chapter 19}

Soils and their radiometric characteristics

DOI: https://doi.org/10.7486/DRI.mp495t62g

\section{Chapter 20}

Modelling in-house radon potential using Tellus data and geology to supplement inhouse radon measurements

DOI: https://doi.org/10.7486/DRI.ns06hm86z

\section{Chapter 21}

Determining geochemical threshold values from the Tellus data sets: the examples of zinc and iodine| DOI: https://doi.org/10.7486/DRI.r2087418g

\section{Chapter 22}

Identification of the geochemical signatures of diffuse pollution in the Tellus Border soil data set, using source apportionment

DOI: https://doi.org/10.7486/DRI.wh24m698d

\section{Chapter 23}

Stream sediment background concentrations in mineralised catchments in Northern Ireland: assessment of 'pressures' on water bodies in fulfilment of Water Framework Directive objectives DOI: https://doi.org/10.7486/DRI.x633tf86g

\section{Chapter 24}

Mapping metallic contamination of soils in the Lower Foyle catchment

DOI: https://doi.org/10.7486/DRI.9k42bv355

\section{Chapter 25}

Refining the human health risk assessment process in Northern Ireland through the use of oral bioaccessibility data

DOI: https://doi.org/10.7486/DRI.9p29cr199

\section{Chapter 26}

Combining environmental and medical data sets to explore potential associations between environmental factors and health: policy implications for human health risk assessments

DOI: https://doi.org/10.7486/DRI.9s16dn03n

\section{Chapter 27}

Mapping a waste disposal site using Tellus airborne geophysical data

DOI: https://doi.org/10.7486/DRI.9w03fh87q

\section{Chapter 28}

The use of aero-magnetics to enhance a numerical groundwater model of the Lagan Valley aquifer, Northern Ireland

DOI: https://doi.org/10.7486/DRI.9z90gd711

\section{Chapter 29}

Carbon sequestration in the soils of Northern Ireland: potential based on mineralogical controls DOI: https://doi.org/10.7486/DRI.b277h9556

\section{Chapter 30}

Spatial distribution of soil geochemistry in geoforensics DOI: https://doi.org/10.7486/DRI.b564j6392

\section{End matter}

DOI: https://doi.org/10.7486/DRI.bc38m007j 